Journal of Social Sciences 7 (2): 190-198, 2011

ISSN 1549-3652

(C) 2010 Science Publications

\title{
Ethical Issues in E-Commerce on the Basis of Online Retailing
}

\author{
${ }^{1}$ Sinan Nardal and ${ }^{2}$ Ayse Sahin \\ ${ }^{1}$ Department of International Trade, School of Applied Sciences, Celal Bayar University, \\ 45040 Manisa, Turkey \\ ${ }^{2}$ Department of Business, Faculty of Economics and Administrative Sciences, \\ University of Mersin, Ciftlikkoy Campus, 33343 Mersin, Turkey
}

\begin{abstract}
Problem statement: The rapid spread of e-commerce has created tremendous opportunities for economic efficiency and customer choice. Use of the global Internet computer network for ecommerce activities provides some advantages to the consumers on their daily life. On the other hand Internet represents a new environment for unethical behavior. While e-commerce has witnessed extensive growth in last decade, consumers concerns regarding ethical issues also continue to increase. Even many consumers and businesses are reveling in e-commerce; consumer problems related to online retail become the dark side of the issue. Approach: A survey on 400 online shoppers was conducted (three cities in Turkey (Izmir, Manisa, Mersin) in order to measure consumers' perceptions regarding the ethical issues of online retailing by using scale of Consumers' Perceptions regarding to Ethics of Online Retailers (CPEOR). Results: Ethical problems like security, privacy, reliability and non deception on Internet are core issues that limit the growth of online retailing. Conclusion/Recommendation: Findings indicate that; four factors (security, privacy, non deception and reliability) are strongly predictive of online consumers' satisfaction. Also, this research will be beneficial to online retailers on their online retailing activities.
\end{abstract}

Key words: Ethical issues, e-commerce, online retailing activities, privacy policies, internet sites, security features, unethical behavior

\section{INTRODUCTION}

A broad definition of e-commerce is the use of telecommunications and computers to facilitate the trade of goods and services. E-commerce technology is considered the new wave of IT (Saad and Zayed, 2010). It is an important trade channel without distance between products and consumers (Lucian and Farias, 2009). Online retailing activities have grown dramatically in the past few years and is poised to grow even more so. E-commerce provides information to visitors and allowed retailers for targeting, positioning and delivering goods and services to match their needs and wants continuously (Dangi and Singh, 2010). Some issues, such as privacy, security and other ethical problems continue to be hotly debated in literature. For example recent research conducted on 1009 USA consumers in 2005 indicated that; one of four American consumers wouldn't shop online because of Internet security concerns (Roman, 2007).

The incredible growth of e-commerce presents ethical issues by the way Internet represents new environment for unethical behavior (Freestone and
Michell, 2004). Although many businesses are acknowledging the importance of e-commerce and online retailing activities, little attention has been given to the business community's perceptions of the ethicality of this new medium (Bush et al., 2000). Although there are many different types of Internet sites (such as online newspaper, portals, free down-load sites, customer to customer sites like eBay) but this research is focused on online shopping sites like 'limango.com', 'markafoni.com', 'hepsiburada.com', “amazon.com' and 'eBay.com' so forth.

It takes time to integrate morality into ecommerce activities (Mahmoud et al., 2006). According to Albers-Miller (1999); "when there is a lack of fear of punishment, people do engage in inappropriate behavior" and the online retailing has paved the way for many new forms of aberrant behavior, of which some are entirely new and others are technologically updated versions of long standing ethical debates (Freestone and Michel, 2004). Internet is very composition involves different mediums including television, telephone lines and print. Thus these unique characteristics make the Internet difficult

Corresponding Author: Sinan Nardal1, Department of International Trade, School of Applied Sciences, Celal Bayar University, 45040 Manisa, Turkey Tel: 90 236. 2330949 Fax: 902362336132 
to regulate. Citera et al. (2005) revealed that; ethical transgressions are more likely to happen in etransactions as compared to face to face transaction.

The main purpose of this study attempts to offer more insights into the consumers' perceptions regarding the ethical issues of online retailing in Turkey. In the second part of this study, e-commerce and important issues related to consumers' privacy protection in ecommerce and other ethical issues in online retailing are analyzed.

In this research, a scale which is developed by Roman (2007) about the ethics of online retailers (Consumers' Perceptions Regarding to Ethics of Online Retailer (CPEOR) is used. In the survey, we tested the four factors (security, privacy, non-deception and reliability) of CPEOR scale more rigorously in TurkeyManisa, Izmir and Mersin cities.

Previous research: Retailing emerged in the last two centuries. R.H. Macy opened his first dry goods store in 1858. And in 1930, Marshall Field opened first department store in Illinois. Today many retailers like discount stores, superstores and home shopping cable networks have provided consumers with new shopping options (Wirtz et al., 2007).

Difference between traditional retail format and eretailing is technology. As a result of relative success, especially in terms of sales volume, many of largest retailers (such as Wall-Mart, Tesco and Sears) have integrated online retailing into their existing operations (Grewall et al., 2004).

Technological breakthroughs, especially on information and computer technology have brought unprecedented benefits to economies worldwide (Mudiarasan et al., 2008). Waclauski (2000) projected that; with in the next ten years the Internet will become the primary mode of communication and commerce within the USA.

However, shifting marketing and customer service to the internet also poses great challenges, including the emergence of serious ethical problems and resulting negative consumer responses (Wirtz et al., 2007).

Past research on online retailing has primarily focused on privacy issues but (e.g., Wirtz et al., 2007; Beltramini, 2003; Belanger et al., 2002; Caudill and Murphy, 2000; Menestrel et al., 2002; Maury and Kleiner, 2002; Palmer, 2005; Pollach, 2005; Sama and Shoaf, 2002; Siplor et al., 2004; Stead and Gilbert, 2001) ignored other important ethical marketing issues surrounding the Internet such as security, non deception and reliability so forth. Thus little research has been conducted on the potential ethical issues related to marketing on the Internet and online retailing firms' activities.

\section{MATERIALS AND METHODS}

The main purpose of this research is to measure consumers' perceptions regarding the ethics of online retailers. Although there are many different types of Internet sites (such as online newspaper, portals, free down-load sites, customer to customer sites like eBay) but this research is focused on online shopping sites like 'amazon.com', 'hepsiburada.com', 'limango.com' and 'markafoni.com' so forth.

Sample and data collection: For this research data are collected in three large cities (Manisa, Mersin and Izmir) of Turkey and quota sampling technique was employed according to these cities population density. A convenience sampling technique is used for sample population selection because it is readily available and convenient on the basis of availability (Struwing and Stead, 2001). Data are provided by face-to-face interviews. In all 530 responses are obtained of which 500 questionnaire forms contained complete information and used in statistical analysis. (In Izmir 295 questionnaires are presented of which 280 respondents completed these forms; in Manisa in all 115 responses are obtained of which 105 contained complete information; in Mersin in all 120 responses are obtained of which 115 completed questionnaire forms). These respondents were requested to answer the questionnaire based on their latest online purchase.

Questionnaire design: In this study a questionnaire was used which is developed by Roman (2007) as an instrument for primary data collection related to customers online purchasing habits. In this scale (Roman, 2007) there was nineteen items which are related to consumers' perceptions regarding the ethics of online retailers.

Hypotheses and research model: To address consumers' perceptions regarding the ethical issues of online retailing in Turkey we have established the following hypotheses that we intended to test utilizing the survey results:

Hypothesis 1: There is at least one significantly different city among others in the perception of consumers' about online retailing sites have adequate security features.

Hypothesis 2: There is at least one significantly different city among others in the perception of consumers' about online retailing sites comply with privacy policies. 


\section{J. Social Sci., 7 (2): 190-198, 2011}

Hypothesis 3: There is at least one significantly different city among others in the perception of consumers' online retailing sites truthfulness about their offerings.

Hypothesis 4: There is at least one significantly different city among others in the perception of consumers online retailing sites reliability is high.

The survey results and associated hypotheses testing have been presented in the following part of this study.

\section{RESULTS}

Five hundred respondents participated in the survey. About $47 \%$ of the subjects were male. The socio-demographic profile of the sample from different cities can be seen in Table 1-3.
Table 1 describes the sample characteristics of the returned 280 usable respondents in Izmir. About 52\% of all participants were female; $48 \%$ were male. The sample is relatively young and $98 \%$ of the respondents younger than 30 years and $46 \%$ of respondents are university students or graduates.

A profile of sample from Manisa is presented in Table 2. Approximately $50 \%$ of respondents is student while most of them are at the university level. And all subjects ranged in ages between 18 and 30 years old while $56 \%$ are young and under 21 years old. $93 \%$ of all participants had monthly personal income of 1000 $\mathrm{TL}$ and less than $1000 \mathrm{TL}$. The income figures of Manisa are also similar to Izmir.

Table 1: Socio-demographic profile of the sample from İzmir $(n=280)$

\begin{tabular}{|c|c|c|c|c|c|c|}
\hline \multirow[b]{2}{*}{ Gender } & \multicolumn{5}{|c|}{ (Frequency-\%) } & \\
\hline & Male (146) $(52 \%)$ & & & Female (134) (48\%) & & \\
\hline$\overline{\text { Age }}$ & $\begin{array}{l}20-< \\
(98)(35 \%)\end{array}$ & & $\begin{array}{l}21-30 \\
(178)(63 \%)\end{array}$ & & $\begin{array}{l}31-40 \\
\text { (4) }(2 \%)\end{array}$ & \\
\hline $\begin{array}{l}\text { Education } \\
\text { Level }\end{array}$ & $\begin{array}{l}\text { Elementry education } \\
\text { (13) }(5 \%)\end{array}$ & & $\begin{array}{l}\text { High school } \\
(136)(49 \%)\end{array}$ & $\begin{array}{l}\text { University student } \\
\text { (99) }(35 \%)\end{array}$ & $\begin{array}{l}\text { University graduate } \\
\text { (31) }(11 \%)\end{array}$ & \\
\hline Profession & $\begin{array}{l}\text { Self-employment } \\
\text { (2) }(1 \%)\end{array}$ & $\begin{array}{l}\text { Private ssector } \\
\text { (1) }(1 \%)\end{array}$ & $\begin{array}{l}\text { State sector } \\
(11)(4 \%)\end{array}$ & $\begin{array}{l}\text { Unemployment } \\
\text { (2) }(1 \%)\end{array}$ & $\begin{array}{l}\text { Student } \\
\text { (261) (92\%) }\end{array}$ & $\begin{array}{l}\text { Others } \\
\text { (3) }(1 \%)\end{array}$ \\
\hline $\begin{array}{l}\text { P. Income } \\
\text { Monthly (TL) }\end{array}$ & $\begin{array}{l}500-< \\
(157)(56 \%)\end{array}$ & $\begin{array}{l}501-1000 \\
(75)(26 \%)\end{array}$ & $\begin{array}{l}1001-1500 \\
(22)(8 \%)\end{array}$ & $\begin{array}{l}1501-2000 \\
(16)(5 \%)\end{array}$ & $\begin{array}{l}2001-2500 \\
\text { (3) }(1 \%)\end{array}$ & $\begin{array}{l}2500-> \\
\text { (7) }(3 \%)\end{array}$ \\
\hline
\end{tabular}

Table 2: Socio-demographic profile of the sample from Manisa $(n=105)$

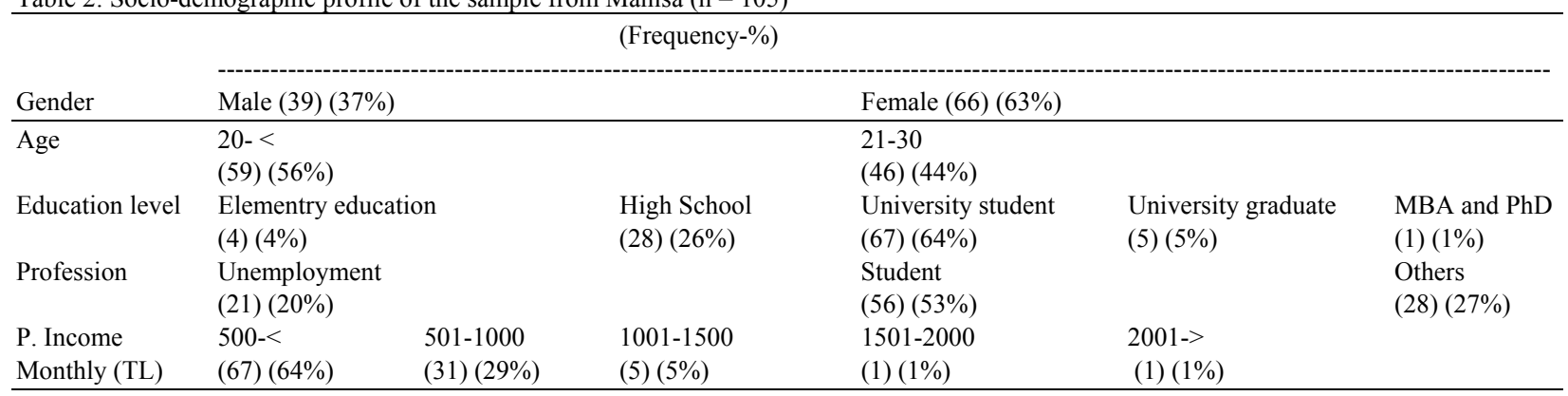

Table 3: Socio-demographic profile of the sample from Mersin $(n=115)$

\begin{tabular}{lllllll}
\hline \multicolumn{7}{c}{ (Frequency-\%) } \\
Gender & Male (50) (44\%) & \multicolumn{5}{c}{ Female (65) (56\%) } \\
\hline Age & $20-<$ & $21-30$ & $31-40$ & $41-50$ & $51-60$ & $60->$ \\
& $(5)(4 \%)$ & $(61)(53 \%)$ & $(23)(20 \%)$ & $(17)(16 \%)$ & $(4)(3 \%)$ & $(5)(4 \%)$ \\
Education level & Elementry education & & High school & University student & University graduate & MBA and PhD \\
& $(5)(5 \%)$ & & $(27)(24 \%)$ & $(55)(47 \%)$ & $(27)(23 \%)$ & $(1)(1 \%)$ \\
Profession & Self-employment & private ssector & State sector & Unemployment & Student & Others \\
& $(10)(9 \%)$ & $(21)(18 \%)$ & $(37)(33 \%)$ & $(7)(6 \%)$ & $(34)(29 \%)$ & $(6)(5 \%)$ \\
P. Income & $500-<$ & $501-1000$ & $1001-1500$ & $1501-2000$ & $2001-2500$ & $2500->$ \\
Monthly (TL) & $(21)(18 \%)$ & $(29)(25 \%)$ & $(18)(17 \%)$ & $(21)(18 \%)$ & $(13)(11 \%)$ & $(13)(11 \%)$ \\
\hline
\end{tabular}




\section{J. Social Sci., 7 (2): 190-198, 2011}

Table 4: Items retained based on exploratory factor analysis $(n=280)$ İzmir

\begin{tabular}{|c|c|c|c|c|}
\hline Item & Security & Reliability & Non deception & Privacy \\
\hline \multicolumn{5}{|l|}{ Security } \\
\hline The security policy is easy to understand & 0.69 & & & \\
\hline $\begin{array}{l}\text { The site displays the terms and conditions of the online } \\
\text { transaction before the purchase has taken place }\end{array}$ & 0.74 & & & \\
\hline It provides information about the company behind the site & 0.67 & & & \\
\hline The site appears to offer secure payment methods & 0.71 & & & \\
\hline You can confirm the details of the transaction before paying & 0.69 & & & \\
\hline \multicolumn{5}{|l|}{ Reliability } \\
\hline The price shown on the site is the actual amount billed & & 0.66 & & \\
\hline You get what you ordered from this site & & 0.76 & & \\
\hline The products I looked at were available & & 0.75 & & \\
\hline Promises to do something by a certain time. they do it & & 0.75 & & \\
\hline \multicolumn{5}{|l|}{ Non-deception } \\
\hline The site exaggerates the benefits and characteristics of its offerings & & & 0.70 & \\
\hline The site uses misleading tactics to convince consumers to buy its products & & & 0.80 & \\
\hline This site takes advantage of less experienced consumers to make them purchase & & & 78.00 & \\
\hline This site attempts to persuade you to buy things that you do not need & & & 0.63 & \\
\hline \multicolumn{5}{|l|}{ Privacy } \\
\hline This site has adequate security features & & & & 0.70 \\
\hline Only the personal information necessary for the transaction to be completed neec & to be provided & & & 0.79 \\
\hline
\end{tabular}

Table 5: Items retained based on exploratory factor analysis $(\mathrm{n}=105)$ Manisa

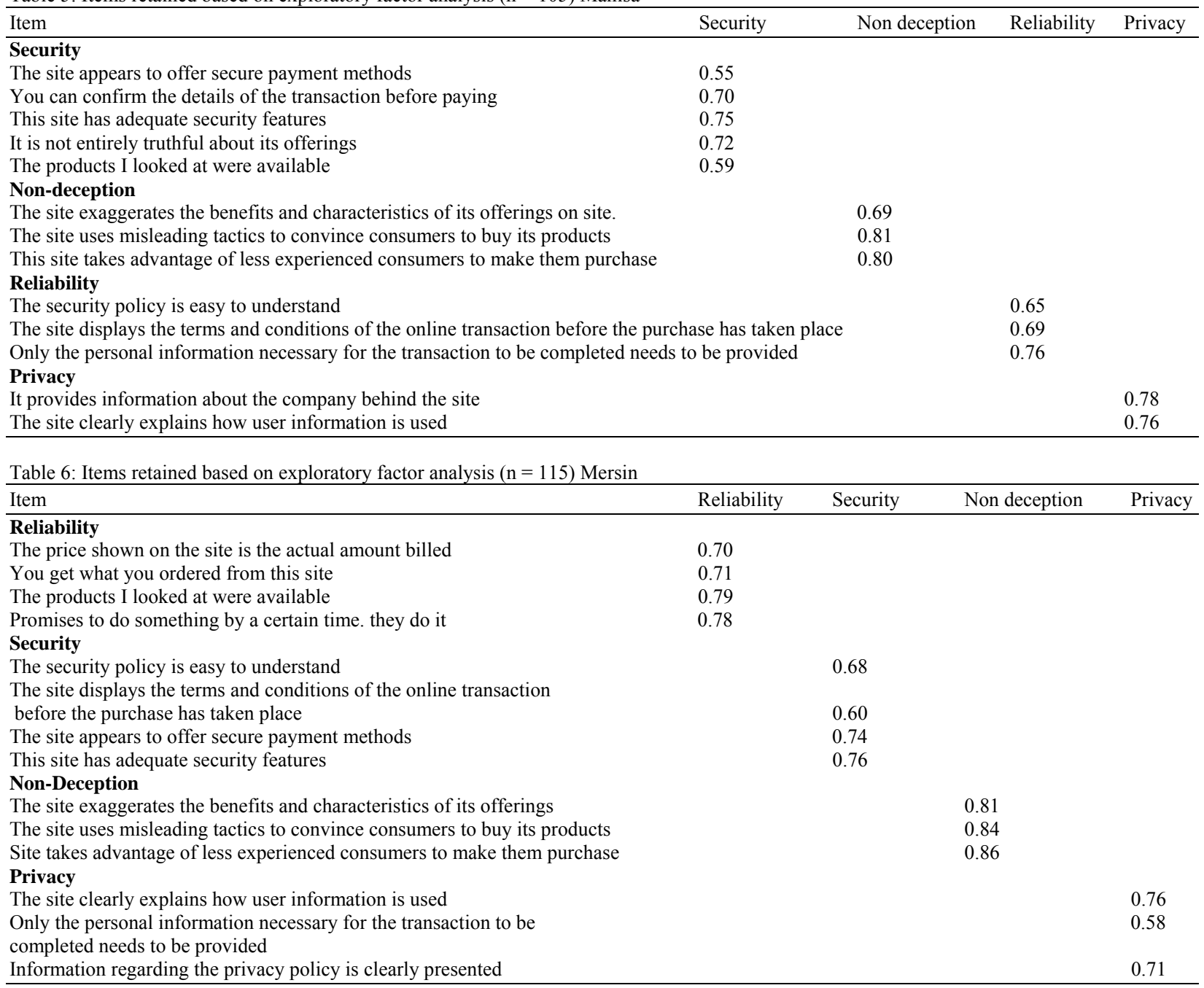


Table 7: Test of homogeneity of variances

\begin{tabular}{lllll}
\hline & Levene statistic & df1 & df2 & Sig \\
\hline Security & 2.787 & 2 & 497 & 0.063 \\
Privacy & 2.792 & 2 & 497 & 0.062 \\
Non deception & 2.076 & 2 & 497 & 0.127 \\
Reliability & 2.306 & 2 & 497 & 0.101 \\
\hline
\end{tabular}

115 respondents volunteered to participate in the study from Mersin. A total of 115 participants were interviewed. $44 \%$ of all participants were female; $56 \%$ were male. Majority of these participants (57\%) were in the age group of 20-30 years. Most of the participants $(76 \%)$ were educated up to university graduate.

Factor and item analysis: To investigate consumers' perceptions regarding the ethics of online retailers' factor analysis were run on scale items for each city (İzmir, Mersin and Manisa) in Turkey as shown in Table 4-6.

In Izmir, data was collected from 280 participants (146 males; 134 females). The Kaiser-Meyer-Olkin (KMO) measure of sampling adequacy was 0.80 indicating that the variable has strong relationships with each other. The minimum amount of data for factor analysis was satisfied, with a final sample size of 280 with over 14 cases per variable. And the four factor solution, which explained $55 \%$ of the variance, was preferred. During several steps, a total of two items ( 8 and 12) were eliminated because they did not contribute to a simple factor structure and failed to meet a minimum criteria of having a primary factor loading. After conducted exploratory factor analysis four distinct factors were identified. First factor, 'security' (Alpha $=79 \%$ ) explains the $18 \%$ of the variance and this factor consists five items like "The site displays the terms and conditions of the online transaction before the purchase has taken place" or "It provides information about the company behind the site". Second factor 'reliability', (Alpha $=70 \%$ ) explains the $14 \%$ of the variance and consists four items like "You get what you ordered from this site". Third factor "non deception', $($ Alpha $=72 \%)$ explains the $13 \%$ of the variance and consists four items like, "The site uses misleading tactics to convince consumers to buy its products". The last factor 'privacy' (Alpha $=55 \%$ ) explains the $10 \%$ of the variance and consists only two items like, "Only the personal information necessary for the transaction to be completed needs to be provided".

As indicated in Table 5, total data was collected from 105 participants in Manisa, (66 males; 39 females) $62 \%$ with an age of 30 and $<30$ years. Secondly the Kaiser-Meyer-Olkin (KMO) measure of sampling adequacy was 0.72 above the recommended value.
With the limitation of small sample size the four factors solution, which explained $53 \%$ of the variance, was preferred. During several steps, a total of two items (10-16) were eliminated because they did not contribute to a simple factor structure and failed to meet a minimum criteria of having a primary factor loading.

After conducted exploratory factor analysis four distinct factors were identified. First factor was related to, 'security' issues on online retailing and (Alpha = $78 \%$ ) explains the $17 \%$ of the variance and this factor consists of five items like "You can confirm the details of the transaction before paying", "This site has adequate security features" or "The site appears to offer secure payment methods". Second factor "non deception', $($ Alpha $=72 \%$ ) explains the $13 \%$ of the variance and consists three items like "The site uses misleading tactics to convince consumers to buy its products" or "This site takes advantage of less experienced consumers to make them purchase". Third factor 'reliability', $(\mathrm{Alpha}=61 \%)$ explains the $13 \%$ of the variance and consists three items like, "The security policy is easy to understand" or "The site displays the terms and conditions of the online transaction before the purchase has taken place". The last factor 'privacy' $($ Alpha $=59 \%)$ explains the $10 \%$ of the variance and consists only two items like, "It provides information about the company behind the site" and "The site clearly explains how user information is used".

Total data was collected from 115 participants in Mersin, (44 males; 56 females) $57 \%$ with an age of 30 and $<30$ years. The Kaiser-Meyer-Olkin (KMO) measure of sampling adequacy was 0.78 above the recommended value and its indicating that the variables has strong relationships with each other. The minimum amount of data for factor analysis was satisfied, with a final sample size of 115 with over 6 cases per variable. And the four factor solution, which explained $61 \%$ of the variance, was preferred. During several steps, a total of three items $(4,12$ and 15) were eliminated because they did not contribute to a simple factor structure and failed to meet a minimum criteria of having a primary factor loading.

First factor, 'reliability' (Alpha $=79 \%)$ explains the $17 \%$ of the variance and this factor consists four items like "The price shown on the site is the actual amount billed", "The products I looked at were available" or "Promises to do something by a certain time, they do it". Second factor 'security', (Alpha = $71 \%$ ) explains the $17 \%$ of the variance and consists four items like "The site appears to offer secure payment methods" or "This site has adequate security 
features". Third factor 'non deception', (Alpha = 83\%) explains the $15 \%$ of the variance and consists three items like, "The site uses misleading tactics to convince consumers to buy its products" or "This site takes advantage of less experienced consumers to make them purchase". The fourth factor 'privacy' (Alpha $=60 \%$ ) explains the $12 \%$ of the variance and consists three items like, "Only the personal information necessary for the transaction to be completed needs to be provided" and "Information regarding the privacy policy is clearly presented".

Results of ANOVA: First of all we transform data in order to meet an assumption of one-way ANOVA test. In other words, in order to apply ANOVA test we collapsed factors' variables, to create new variables for each of them. Before implement one-way ANOVA test we checked homogeneity of variances as seeing Table 7.
Because $\alpha$ level is selected as 0.05 (confidence level is 0.95), the p-values should be greater than $\alpha$ level in order to fail to reject the null hypothesis. As seen from Table 7 , the significance value for homogeneity of variances is $>.05$, so the variances of the groups are assumed to be homogenous.

Then one-way ANOVA is used to test for variance among three cities' independent groups of data. Tests were carried out to investigate attitudinal variances in each of the three cities. The results of these analyses were as follows (Table 8-9)

The ANOVA Table also shows the statistics used to test hypotheses about the factors whether they are significant or not; typically compare against $\alpha$ value of 0.05 . If the $p$-value is lower than $\alpha$ value, then the corresponding factor is significant.

Table 8: ANOVA Table

\begin{tabular}{|c|c|c|c|c|c|c|}
\hline & & Sum of squares & Df & Mean square & $\mathrm{F}$ & Sig. \\
\hline \multirow[t]{3}{*}{ Security } & Between groups & 3.451 & 2 & 1.725 & 3.399 & 0.034 \\
\hline & Within groups & 252.267 & 497 & 0.508 & & \\
\hline & Total & 255.718 & 499 & & & \\
\hline \multirow[t]{3}{*}{ Privacy } & Between groups & 0.275 & 2 & 0.138 & 0.253 & 0.777 \\
\hline & Within groups & 270.731 & 497 & 0.545 & & \\
\hline & Total & 271.006 & 499 & & & \\
\hline \multirow[t]{3}{*}{ Nondeception } & Between groups & 18.283 & 2 & 9.141 & 15.898 & 0.000 \\
\hline & Within groups & 285.765 & 497 & 0.575 & & \\
\hline & Total & 304.048 & 499 & & & \\
\hline \multirow[t]{3}{*}{ Reliability } & Between groups & 12.667 & 2 & 6.333 & 10.450 & 0.000 \\
\hline & Within groups & 301.200 & 497 & 0.606 & & \\
\hline & Total & 313.866 & 499 & & & \\
\hline
\end{tabular}

Table 9: Multiple comparisons

\begin{tabular}{|c|c|c|c|c|c|c|c|}
\hline \multirow[b]{2}{*}{ Dependent variable } & \multirow[b]{2}{*}{ (I) City } & \multirow[b]{2}{*}{ (J) City } & \multirow[b]{2}{*}{$\begin{array}{l}\text { Mean difference } \\
(\mathrm{I}-\mathrm{J})\end{array}$} & \multirow[b]{2}{*}{ Std. error } & \multirow[b]{2}{*}{ Sig. } & \multicolumn{2}{|c|}{$95 \%$ Confidence Int. } \\
\hline & & & & & & Lower bound & Upper bound \\
\hline \multirow[t]{6}{*}{ Security } & Izmir & Manisa & 0.04028 & 0.08153 & 0.874 & -0.1514 & 0.2319 \\
\hline & & Mersin & -0.18284 & 0.07891 & 0.054 & -0.3683 & 0.0027 \\
\hline & Manisa & Izmir & -0.04028 & 0.08153 & 0.874 & -0.2319 & 0.1514 \\
\hline & & Mersin & -0.22312 & 0.09617 & 0.054 & -0.4492 & 0.0029 \\
\hline & Mersin & Izmir & 0.18284 & 0.07891 & 0.054 & -0.0027 & 0.3683 \\
\hline & & Manisa & 0.22312 & 0.09617 & 0.054 & -0.0029 & 0.4492 \\
\hline \multirow[t]{6}{*}{ Privacy } & Izmir & Manisa & 0.05506 & 0.08446 & 0.791 & -0.1435 & 0.2536 \\
\hline & & Mersin & -0.00726 & 0.08175 & 0.996 & -0.1994 & 0.1849 \\
\hline & Manisa & Izmir & -0.05506 & 0.08446 & 0.791 & -0.2536 & 0.1435 \\
\hline & & Mersin & -0.06232 & 0.09962 & 0.806 & -0.2965 & 0.1719 \\
\hline & Mersin & Izmir & 0.00726 & 0.08175 & 0.996 & -0.1849 & 0.1994 \\
\hline & & Manisa & 0.06232 & 0.09962 & 0.806 & -0.1719 & 0.2965 \\
\hline \multirow[t]{6}{*}{ Non deception } & Izmir & Manisa & -0.06119 & 0.08677 & 0.761 & -0.2652 & 0.1428 \\
\hline & & Mersin & $0.43413(*)$ & 0.08398 & 0.000 & 0.2367 & 0.6316 \\
\hline & Manisa & Izmir & 0.06119 & 0.08677 & 0.761 & -0.1428 & 0.2652 \\
\hline & & Mersin & $0.49532(*)$ & 0.10235 & 0.000 & 0.2547 & 0.7359 \\
\hline & Mersin & Izmir & $-0.43413(*)$ & 0.08398 & 0.000 & -0.6316 & -0.2367 \\
\hline & & Manisa & $-0.49532(*)$ & 0.10235 & 0.000 & -0.7359 & -0.2547 \\
\hline \multirow[t]{6}{*}{ Reliability } & Izmir & Manisa & 0.06964 & 0.08909 & 0.714 & -0.1398 & 0.2791 \\
\hline & & Mersin & $-0.35365(*)$ & 0.08622 & 0.000 & -0.5563 & -0.1510 \\
\hline & Manisa & Izmir & -0.06964 & 0.08909 & 0.714 & -0.2791 & 0.1398 \\
\hline & & Mersin & $-0.42329(*)$ & 0.10508 & 0.000 & -0.6703 & -0.1763 \\
\hline & Mersin & Izmir & $0.35365\left(^{*}\right)$ & 0.08622 & 0.000 & 0.1510 & 0.5563 \\
\hline & & Manisa & $0.42329(*)$ & 0.10508 & 0.000 & 0.1763 & 0.6703 \\
\hline
\end{tabular}

*: The mean difference is significant at the 0.05 levels 
Interpreting the $p$-values from the ANOVA Table (Table 8); except the privacy factor, (Hypothesis 2: There are mean differences of cities in the perception of consumers about online retailing sites comply with privacy policies) all other factors (security, non deception and reliability) are significant. Multiple comparisons results: Multiple comparisons are made according to the Tukey's method to create confidence intervals for all pairwise differences between factor level means. As seen from the Table 9, for the non deception and reliability dependent variables İzmir and Manisa show significant mean differences as compared to Mersin and also Mersin shows significant mean differences to İzmir and Manisa as a comparison, interactively. İzmir and Manisa show no significant mean difference at any factor (dependent variable) between each other.

\section{DISCUSSION}

According to the multiple comparisons' results, Hypothesis 1 (There are mean differences of cities in the perception of consumers about online retailing sites have adequate security features) and Hypothesis 2 (There are mean differences of cities in the perception of consumers about online retailing sites comply with privacy policies) are failed to reject all pair wise comparisons for security and privacy dependent variables.

Consumers who participate in this research from Izmir, Manisa and Mersin cities have no significant mean difference in the perception of about security features and privacy policies of online retailing. On the contrary, Hypothesis 3 and Hypothesis 4 are rejected. For non deception variable, the participants from Mersin has significant mean differences as compared to cities Izmir and Manisa.

As seen in Table 9, the p-values for each pair wise condition are zero and the related confidence intervals do not contain the zero value which means significant difference occurred.

The findings for three cities appear to be equally concerned about security (problems like security of payments), privacy (policies like confidentiality of personal information), reliability (integrity of returns) and non deception (integrity of refunds) factors. That the level of concern is high suggests that online retailers need to be more proactive in their efforts related to these four ethical issues. These issues are key elements of resulting negative consumer responses and undermine online retailers marketing performance in the long run.

\section{CONCLUSION}

The Internet is a free marketplace for the exchange of ideas, goods and services. Besides many opportunities, it has a lot of ethical problems for consumers. This study examines how ethical problems influence consumers' online buying concern and the resulting consequences on these buyers' behavior.

Ethical problems treat to consumer privacy. A commercial site and advertiser can through an agreement related to getting a copy of the personal information a customer supplied the shopping site and subsequently associate the information with the customers' browser. Regarding personal information privacy, once you let your information out on the web, it's too hard to get it back. On the other hand cookies gather consumers' information secretly and currently there are no legal limits on how cookies are used. At this point some consumers feel that; personal information gathered secretly by cookies will result in loss of privacy. It forces online retailers to think and to determine about what sort of privacy protection policies they will put into place. Today most of online retailer posted new privacy policies to their customers. Companies' activities like adopting strict privacy policies and protection of online buyers will be rewarded by their consumers.

E-retailers have to realize that in order to succeed ecommerce efforts must match the consumer needs related to security (Krishnamurthy, 2006). Today it is essential that more people should be made to feel comfortable shopping online and providing some level of consumer protection may be a way to aid in this process. In this situation, ethical issues are important in e-commerce and online retailing to establish a trustworthy, secure online environment and consumer confidence.

At online retailing activities most of the ethical problems are related to "reliability". Unethical activities may have negative consequences for firm well-being by eroding consumer trust (Babin et al., 2004). Many consumers do not trust the security of e-commerce. Therefore consumer adaptation to e-commerce need many activities related to reliability, privacy, security and non deception issues.

While more extensive studies need to be conducted to understand fully ethical factors affecting consumer behavior, overall the finding support that consumers do 


\section{J. Social Sci., 7 (2): 190-198, 2011}

not feel they can rely on the integrity of the online retailer thus put little trust in online stores.

The results offer important implications for web site design strategies.

Today there are no consensus on universally accepted privacy policy standards has been negotiated. And only a fraction of web sites have 'useful' privacy policies. The majority of web merchants do not subscribe to online privacy seal programs. In the world governments have considered many legislative actions to regulate how web operators obtain and use consumer information. Such legislations require customers' permission before disclose personal information.

Unique characteristics make the Internet difficult to regulate. So further investigation is needed as to have developing a code of ethics about online retailing.

The results of this study show that high levels of concern about privacy and security issues however little attention has given to other ethical issues like reliability and non deception by online retailers. Further studies could usefully be undertaken by online retailers in relation to reliability and non deception issues.

This exploratory study has a number of limitations, including a convenience sample comprising online buyers. Our study focused on only three cities while it may be applicable to other big cities of Turkey. Also this research may be applicable to different countries in order to make international comparisons. Finally, there is lack of scientific research examining the online retailing ethics and concern of consumers' in Turkey.

\section{REFERENCES}

Albers-Miller, N.D., 1999. Consumer misbehavior: Why people buy illicit goods. J. Cons. Market, 16: 273287. DOI: $10.1108 / 07363769910271504$

Babin, B.J., M. Griffin and J.S. Boles, 2004. Buyer reactions to ethical beliefs in the retail environment. J. Bus. Res., 57: 1155-1163. DOI: 10.1016/S01482963(02)00329-6

Belanger, F., J.S. Hiller and W.J. Smith, 2002. Trustworthiness in electronic commerce: The role of privacy, security and site attributes. J. Strategic Inform. Syst., 11: 245-270. DOI: 10.1016/S09638687(02)00018-5

Beltramini, R.F., 2003. Application of the unfairness doctrine to marketing communications on the internet. J. Bus. Ethics., 42: 393-400. DOI: 10.1023/A:1022521811932

Bush, V. D., B.T. Venable and Alan J. Bush, 2000. Ethics and marketing on this internet: Practitioners' perceptions of societal, industry and company concerns. J. Bus. Ethics., 23: 237-248. DOI: 10.1023/A:1006202107464
Caudill, E.M. and P.E. Murphy, 2000. Consumer online privacy: Legal and ethical issues. J. Pub. Policy Market., 19: 7-19. DOI: 10.1509/jppm.19.1.7.16951

Citera, M., R. Beauregard and T. Mitsuya, 2005. An experimental study of credibility in e-negotiations. Psychol. Market., 22: 163-179. DOI: 10.1002/mar.20053

Dangi, N. and H. Singh, 2010. e-Choupal: Hope or Hype? Am. J. Econ. Bus. Admin., 2: 179-184. DOI: 10.3844/ajebasp.2010.179.184

Freestone, O. and V. Mitchell, 2004. Generation y attitudes towards E-ethics and internet-related misbehaviors. J. Bus. Ethics., 54: 121-128. DOI: 10.1007/s10551-004-1571-0

Grewal, D., G.R. Iyer and M. Levy, 2004. Internet retailing: Enablers, limiters and market consequences. J. Bus. Res., 57: 703-713. DOI: 10.1016/S0148-2963(02)00348-X

Krishnamurthy, S., 2006. Introducing E-MARKPLAN: A practical methodology to plan e-marketing activities. Bus. Horizons, 49: 51-60. DOI: 10.1016/j.bushor.2005.05.008

Lucian, R. and S. Farias, 2009, effects of information overload on Brazilian e-consumers, Am. J. Econ. Bus. Admin., 1: 21-26. DOI: 10.3844/ajebasp.2009.21.26

Mahmoud, M., Ghaleb E. El-Refae and Shorouq, F. ElEtter, 2006. A rubber band ethics model for computing and information technology practices. Am. J. Applied Sci., 3: 1910-1915. DOI: 10.3844/ajassp.2006.1910.1915

Maury, M.D. and D.S. Kleiner, 2002. E commerce, ethical commerce. J. Bus. Ethics., 36: 21-31. DOI: 10.1023/A:1014274301815

Menestrel, M.L., M. Hunter and H.C. de Bettignies, 2002. Internet e-ethics in confrontation with an activists' agenda: Yahoo! on trial. J. Bus. Ethics., 39: 135144. DOI: $10.1023 / \mathrm{A}: 1016348421254$

Mudiarasan, K., P. Mosayeb and A.S. Saleh, 2008. Fostering ICT development for growth: Measuring the payoffs for Australia and the Asean-5 countries. Am. J. Applied Sci., 5: 1676-1685. DOI: 10.3844/ajassp.2008.1676.1685

Palmer, D.E., 2005. Pop-Ups, cookies and spam: Toward a deeper analysis of the ethical significance of internet marketing practices. J. Bus. Ethics., 58: 271-280. DOI: $10.1007 / \mathrm{s} 10551-005-1421-8$

Pollach, I., 2005. A typology of communicative strategies in online privacy policies: Ethics, power and informed consent. J. Bus. Ethics., 62: 221-235. DOI: 10.1007/s10551-005-7898-3 
Roman, S., 2007. The Ethics of online retailing: A scale development and validation from the consumers' perspective. J. Bus. Ethics., 72: 131-148. DOI: 10.1007/s10551-006-9161-y

Saad, G.Y. and S. Zayed, 2010. Exploring critical determinants in deploying mobile commerce technology. Am. J. Applied Sci., 7: 120-126. DOI: 10.3844/ajassp.2010.120-.126

Sama, L.M. and V. Shoaf, 2002. Ethics on the Web: Applying moral decision-making to the new media. J. Bus. Ethics., 36: 93-103. DOI: 10.1023/A:1014296128397

Siplor, J.C., B.T. Ward and N.M. Rongione, 2004. Ethics of collecting and using consumer internet data. Inform. Syst. Manage., 21: 58-66. DOI: 10.1201/1078/43877.21.1.20041201/78986.6
Stead, B.A. and J. Gilbert, 2001. Ethical issues in electronic commerce. J. Bus. Ethics., 34: 75-85. DOI: $10.1023 / \mathrm{A}: 1012266020988$

Struwing, F.W. and G.B. Stead, 2001. Planning, Designing and Reporting Research. 1st Edn., Pearson Education, South Africa, ISBN: 1868910814, pp: 280.

Waclauski, J., 2000. The Real world: The e-business revolution, faster than a speeding bullet. Ind. Organiz. Psychol., 37: 70-80.

Wirtz, J., M.O. Lwin and J.D. Williams, 2007. Causes and consequences of consumer online privacy concern. Int. J. Service Ind. Manage., 18: 326-348. DOI: $10.1108 / 09564230710778128$ 